\title{
Science gets real at Sundance
}

\section{This year's crop of research-related films moves away from 'mad genius' mode, finds Jascha Hoffman.}

$\mathrm{H}$ ollywood likes its science catastrophic and its researchers portrayed as either reckless geniuses or crazed loners. Will we ever have a realistic rendering of the benign innovators at work in a lab near you? The answer could be a qualified yes, judging from the lineup at this year's Sundance Film Festival in Utah.

The cinematic celebration, now in its 34th year, promotes US film outside Hollywood and has launched the career of directors such as Steven Soderbergh, whose epidemiological thriller Contagion did well last year. For 2012, the festival has embraced the bright side of science in its documentary-heavy programme.

"Most of these films are positive in their view of science as a means to improve our lives," said John Nein, a film programmer at the Sundance Institute in Los Angeles, California. Many of the festival's 100 or so features bear out Nein's words.

Among a handful of documentaries concerned with climate, energy and the environment, one stands out

\section{$\rightarrow$ NATURE.COM}

For Isabella

Rosselini's take on science and film: go.nature.com/urek25
Sundance Film

Festival

Park City, Utah

Until 29 January.

time-lapse footage of glaciers melting and ice shelves collapsing. The result is a graphic portrait of global warming. Director Mark Kitchell's A Fierce Green Fire is a sweeping history of environmental activism in the past half-century, with biologist E. O. Wildirected by Don Argott and Sheena Joyce, sounds a warning of the health and environmental costs of nuclear energy.

Also on the factual front is a set of documentaries showing how science improves public life through education, medicine and criminal justice. In The D Word: Understanding Dyslexia (directed by James Redford, son of Sundance president and founder Robert Redford), physicians from the Yale Center for Dyslexia and Creativity in New Haven, Connecticut, explain the neurological underpinnings of dyslexia, revealing how some of its features may account for the success of entrepreneur Richard Branson and others with the condition.

David France's How to Survive a Plague explores the controversial efforts of AIDS activists in the 1980s and 1990s to push son as adviser. The Atomic States of America,

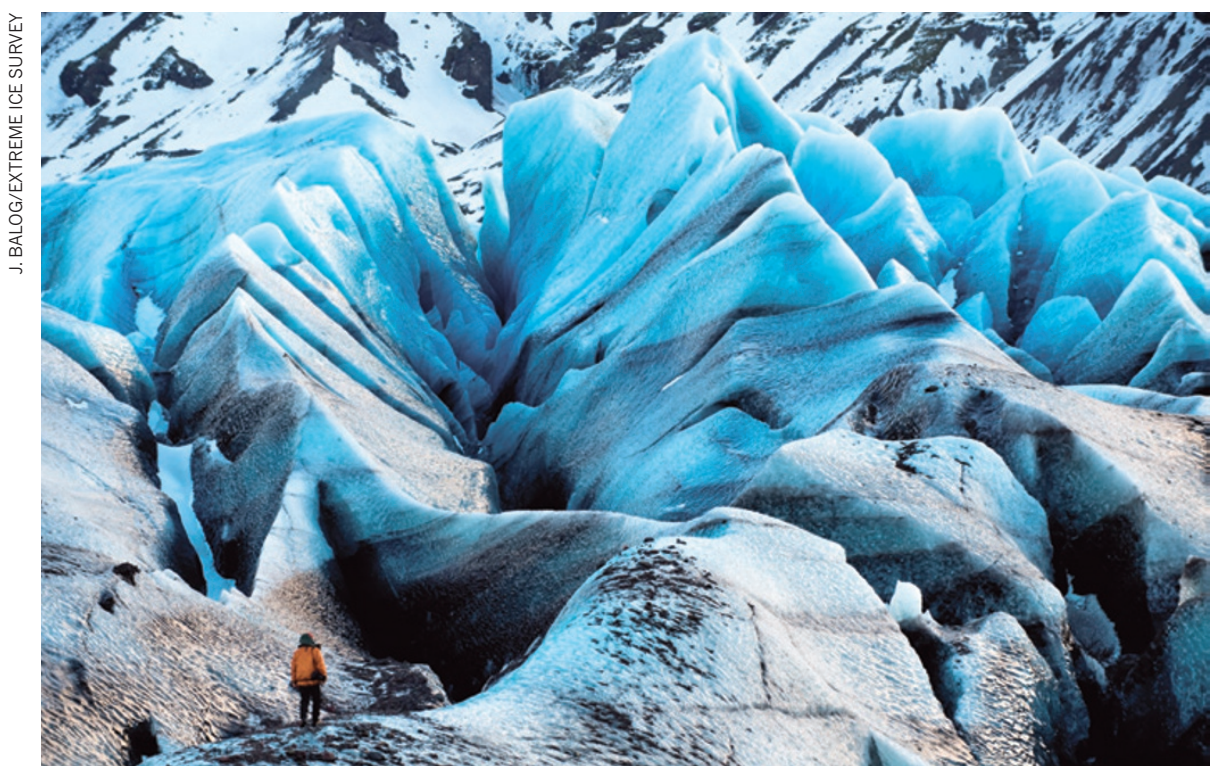

Time-lapse footage of melting glaciers in Chasing Ice offers a graphic glimpse of global warming in action. experimental treatments through the drug pipeline. And West of Memphis, directed by Amy Berg and co-produced by The Hobbit director Peter Jackson, delves into the finer points of forensic science. It tells the story of three Arkansas teenagers who, convicted of murdering three boys, were released two decades later on the basis of DNA evidence.

Other offerings are more personal and research-focused. Homing in on freshwater biology, Chris Peters's The Diatom is a meditative glimpse of a microbiologist tracking the unicellular organisms that thrive in Utah's remote mountain reservoirs. Valley of Saints, directed by Musa Syeed, follows a biologist and the boatman she falls in love with as they discover serious pollution in a pristine lake in Kashmir.

Two star-studded films offer comic relief. Director Jake Schreier's dramatic comedy Robot and Frank recounts the budding friendship between an elderly thief and the household robot that cooks and cleans for him, and claims to illuminate "the implications of humankind's ever-changing relationship with technology". Red Lights, by director Rodrigo Cortés, features a research duo played by Sigourney Weaver and Cillian Murphy as a pair of sceptics who debunk clairvoyants. Until, that is, they discover a blind psychic, unaccountably played by Robert De Niro, whose apparent powers threaten their faith in reason.

Festival-goers may be lured from their seats for conversations on the future of filmmaking. A talk that questions 'the new future normal' speculates on tomorrow's beneficial technologies, from camera contact lenses to regularly upgraded 'hyperhumanity'. A panel on good science in films, sponsored by the Alfred P. Sloan Foundation, will ask what would happen if robots or viruses helped humanity instead of wiping it out. Panellists include biologists Helen Fisher and Robert Full, and Contagion screenwriter Scott Burns.

Science fiction and allegorical drama also get a look-in. Beasts of the Southern Wild, directed by Benh Zeitlin, is a moody film about a six-year-old girl in a flooded world rife with prehistoric creatures. Director Colin Trevorrow's Safety Not Guaranteed is a romantic comedy hinging on time travel. There are even classic blood-spattered forays. In Jon Wright's monster feature Grabbers, "giant, bloodsucking, tentacled aliens" rise from the sea to prey on boozy Irish villagers, despite the efforts of a marine biologist and two local police officers.

There's always room for a little bonecrunching horror - if only for contrast to the nuanced, realistic cinematic science we see dawning at Sundance.

Jascha Hoffman is a journalist based in San Francisco, California. e-mail:jascha@jaschahoffman.com 